Chapter 2

\title{
Pesticide-Residue Relationship and Its Adverse Effects on Occupational Workers
}

\author{
Nabil El-Wakeil, Shehata Shalaby, \\ Gehan Abdou and Ahmed Sallam \\ Additional information is available at the end of the chapter \\ http://dx.doi.org/10.5772/54338
}

\section{Introduction}

Pesticides use in agriculture is the most economical approach to control various pests, though they are considered major contaminant of our environment. The World Health Organization (WHO, 2005) and United Nations Environmental Program have estimated one to five million cases of pesticide poisoning among agricultural workers each year with about 20,000 fatalities, mostly reported from developing countries (Pimental et al. 1992). There are several definitions of pesticide; the Food and Agriculture Organization (FAO) defines pesticide as any substance or mixture of substances intended for preventing, destroying or controlling any pest during the production, processing, storage or marketing of food in all agricultural commodities for controlling the pests (FAO 1986). Pesticides are playing a pivotal role in meeting the food, cotton fibre and tobacco demand of escalating population and control of vector-borne diseases. However, most of the applied pesticides get dispersed in the environment and affects the health of un-protected agricultural and industrial workers. Pesticides are used extensively throughout the world. The three major routes of entry for pesticides include contamination of the skin, mouth and the nose. Although pesticides furnish some benefits for crop, they entail a number of risks and problems. The public health issue of pesticide exposure is further complicated by the presence of impurities in so-called, inert-ingredients such as solvents, wetting agents and emulsifiers (Hashmi\&Dilshad 2011).

The main similarity between pesticide exposure of farm workers' children and lead exposure of children living in poverty is that the substances are present in the home, are difficult for the family to control, and are inequitably distributed across ethnic and socioeconomic groups. Unlike lead, the potential developmental effects of childhood exposure to many 
types of pesticides are greatly understudied. Some pesticides have been shown to cause behavioural effects in rodents such as hyperactivity, learning and memory problems, and altered habituation (Icenogle et al. 2004). In spite of the paucity of research on the effects of pesticides on human neurobehavioral development, there are reasons to be concerned about children's exposure. First, two widely used classes of insecticides, organophosphates and carbamates, inhibit cholinesterase. Cholinesterase inhibition leads to excess acetylcholine at the synapse, which in turn causes over activation of cholinergic neural pathways. There is evidence that organophosphate and carbamate pesticides can negatively affect early life rodent brain development by interfering with gene signalling by cholinesterases as well as by inducing faulty wiring of the brain via other mechanisms (Slotkin 1999; Aldridge et al. 2005; Sallam et al. 2006, 2009a,b).

These chemicals are suspected of producing adverse health effects based on their structural similarity to proven toxicants. Exposure to pesticides is one of the most important occupational risks among farmers in developing countries (Wesseling et al. 2001; Konradsen et al. 2003; Coronado et al. 2004; Shalaby et al. 2012). Occupational exposure to pesticides is of great interest in order to identify the hazards of pesticide use and the establishment of safe methods of pesticide handling. This is because pesticide misuse in various sectors of the agriculture often has been associated with health problems and environmental contamination worldwide (Soares et al. 2003; Mancini et al. 2005; Remor et al. 2009). Misuse of highly toxic pesticides, coupled with a weak or a totally absent legislative framework in the use of pesticides, is one of the major reasons for the high incidence of pesticide poisoning in developing countries (Konradsen et al. 2003; Hurtig et al. 2003; Atreya 2008). In general, knowledge of the main determinants of pesticide exposure in developing countries is often poor and also exposure situations may differ among countries (Hashmi\&Dilshad 2011; Shalaby et al. 2012).

The spray-workers are directly exposed to pesticides during mixing, handling, spray, and through contaminated soil, air, drinking water, eating food and smoking at work places. The farm workers are, therefore, occupationally exposed to pesticides and may absorb them by inhalation, ingestion and dermal contact (Vega 1994; Mathur et al. 2005). The residue concentrations of these compounds in affected workers may lead to a variety of metabolic and systemic dysfunctions and, in some cases, outright disease states. Therefore, the excessive and repeated pesticide use has promoted toxicological problems in spraying community (Brown et al.1989; Karalliede\&Senanayake 1999; Azmi et al. 2006). A major factor of pesticide contamination or poisoning in developing countries is the unsafe use or misuse of pesticides. Elements of unsafe use of pesticides that have been identified by past research include erroneous beliefs of farmers about pesticide toxicity, lack of attention to safety precautions, environmental hazards, and information about first aid and antidotes given by the label, the use of faulty spraying equipment or lack of proper maintenance of spraying equipment, and lack of the use of protective gear and appropriate clothing during handling of pesticides (Hurtig et al. 2003; Damalas et al. 2006a, b; Ajayi\&Akinnifesi 2008; Chalermphol\&Shivakoti 2009; Plianbangchang et al. 2009; Sosan\&Akingbohungbe 2009; Hashmi\&Dilshad 2011). 
In view of the adverse health effects from the unsafe pesticide use, the latency of the adverse effects, the reported lack of awareness of the adverse health effects of pesticides by some farmers, and the erroneous belief of invincibility by others, it becomes imperative that the potential hazards of unsafe pesticide use should be clearly communicated to the farmers. Research has often emphasized the need to increase the awareness of farmers about the consequences of unsafe pesticide use and the importance of communication and education programs aiming to reduction of risk (Ibitayo 2006; Hashemi et al. 2008; Oluwole\&Cheke 2009; Sosan\&Akingbohungbe, 2009; Damalas\&Hashemi 2010)

Exposure to pesticides at any point in the life cycle has the potential for causing a range of short-term or long-term health problems. Documented health effects include a wide variety of illnesses and diseases, from eye irritation, skin rashes and respiratory problems to neurological damage, birth defects, cancer and death. The risk for and severity of adverse health effects from pesticide exposure varies significantly depending on many factors, including individual characteristics such as age and health status, the specific pesticide, and exposure circumstances. Exposure to pesticides at certain developmental stages of life can result in irreversible damage to organ structure and function. Of particular concern is the effect of exposure at during the reproductive cycle, from preconception to breast feeding, because of the possibility of poor birth outcomes, congenital anomalies, developmental deficits, and possibly childhood cancer (Barthel 1981; Karabay et al. 2004; Hernandez et al. 2004; Sanborn et al. 2004; Strong et al. 2004; Hernandez et al. 2006; Hayes et al. 2006; El-Wakeil et al. 2009).

Farm worker families often live near or on the farms on which they work, and thus spend much of their time in close proximity to areas where pesticides are applied on a regular basis. Twenty-one percent of farm workers are women (Carroll et al. 2005), who may be directed to or inadvertently enter recently treated fields while pregnant. Women in farm worker households who do not work in the fields may still be exposed to pesticide residues brought home by farm worker household members on their shoes, clothes and skin; from nearby applications that drift or are directly sprayed on outdoor play areas; and from chemicals used to control pests in and around the home, especially in poor quality housing.

Agricultural extension is a major channel of communication between farmers and research experts which can improve crop production from many points of view as it provides a good link between farmers and research institutes where several agricultural technologies, including pesticides and the relative technology, are developed, tested, and modified accordingly. Training programs can play a crucial role in pest control decisions, providing farmers with the technical knowledge that is necessary for the selection of appropriate pest management methods and also for safe and effective pesticide use. Despite the appearance of homogeneity, often small farmers have different production practices, needs, and constraints (Carr 1989). A successful agricultural extension program, therefore, should not consider all individuals in a target group based on several variables such as age, gender, income, and types of crops (Sallam 2008; Shalaby et al. 2012). 


\section{Exposure pathways}

Pesticides are used in $85 \%$ of homes in the US (Whitmore et al. 1992), but they or their residues can be found even on surfaces that have never been directly or peripherally treated. POPs introduced into the environment years ago are still around today, transported by human activity and through the food chain. Despite being banned in the US (and many other countries) some 30 years ago, traces of these insecticides are still found in the homes and bodies of individuals in the US who were not even alive when these products were used (Weiss et al. 2004; Wolff et al. 2007). Chlorpyrifos (a non persistent OP) has also been found to accumulate on newly-introduced surfaces, such as pillows, carpet and soft toys, when brought into a treated area up to two weeks after application, even if applied according to manufacturer's instructions (Gurunathan et al. 1998).

In agricultural settings, work-to-home exposure, or a "take-home pathway," has been identified as a key source of pesticide residues (primarily to OPs) in children's environment ((Fenske et al. 2000; Curl et al. 2002; Thompson et al. 2003; Rao et al. 2006; Coronado et al. 2006). Workers who are exposed on the job on a daily basis, whether as applicators or re-entry workers, are likely to carry home pesticides on their shoes, clothes, skin, and vehicles. Most workers are not provided with adequate washing or changing facilities to remove residues and put on clean clothes before leaving the worksite. If these workers do not take basic precautions (e.g., removing work shoes outside the dwelling, showering before picking up a child); they may transfer residues to the indoor environment or directly to other household members.

The primary routes by which pesticides enter the body are ingestion in food, soil, or water; inhalation, through the skin, and through the eyes (Arcury et al. 2000). OCs are absorbed through the lungs, stomach and skin, and excreted only slowly, sometimes over a period of years (e.g., DDT) (Pohl \&Tylenda 2000; Cohn et al. 2007). Dietary ingestion is a significant source of exposure, especially for infants and children (Garry 2004). The residue monitoring program conducted by the FDA in 2003 found measurable levels of pesticides in baby foods, including DDT ( $6 \%$ of samples), captan + THPI (a possible carcinogen) $(9 \%)$, carbaryl (carbamate) $(6 \%)$, endosulfan (9\%), dimethoate $(4 \%)$, malathion (3\%), and chlorpyrifos (all OPs) (2\%) (FDA 2005; Sallam et al. 2006).

Post-natally, infants can be exposed to pesticides via breast feeding. The POPs, despite having mostly been banned, are still found in breast milk because they are stored in body fat (Weiss et al. 2004; Jurewicz et al. 2006). Postpartum weight loss increases the likelihood of the release of OCs into the breast milk (Jurewicz et al. 2006). There is some evidence that the maternal body burden is actually transferred to her children via breast feeding, as the pesticide concentrations decrease with the more times a mother has breastfed (Nickerson 2006). Fortunately, the benefits of breast feeding still far outweigh the possibility of harm from pesticide transfer in breast milk, and should be encouraged for all mothers regardless of exposure history (Nickerson 2006; Eskenazi et al. 2006). Pesticides exposure occurs in different ways: dermal, oral, respiratory and conjunctival routes. 


\subsection{Dermal exposure}

It occurs by not washing hands after handling pesticides or their containers. Splashing or spilling of pesticide on skin by wearing pesticide-contaminated clothing and applying pesticides in the windy weather. Touching treated plants or soil also leads to dermal exposure. Exposures occur by rubbing eyes or forehead with pesticides contaminated gloves or hands, splashing pesticides in eyes, application in windy weather, drift exposure and mixing/loading of dry formulations without wearing goggles.

\subsection{Oral exposure}

Hands not washed before eating, smoking or chewing, pesticide splashed into mouth. Accidental application of pesticides to food, storing pesticides in drinking containers and drift on lip or in mouth also leads to oral exposure.

\subsection{Inhalational exposure}

Exposed to drift during or after spraying, mixing/loading, dusts, powders or other dry formulations; use of inadequate or poorly fitted respirators.

\subsection{Exposure on respiratory system}

The crops, activities, and exposure agents that can lead to respiratory disease are extraordinarily diverse and vary significantly by seasons, geography and type of agriculture. The number of substances affecting respiratory health to which a worker is exposed while working in an agricultural setting is enormous: pesticides, including insecticides, herbicides, and fumigants; other agricultural chemicals, including fertilizers and plant growth regulators; the crops and related allergens, such as pollens, pests, and microorganisms; and the land itself, including organic and inorganic dusts, to name just a few (Schenker et al 1998; Schenker 2005). Further complicating the issue, the likelihood that an individual worker has been exposed to but a single identifiable agent is small. Measuring exposure is also challenging, which makes dose-response relationships difficult to assess, and exposure limits have not been set for most relevant agents. Agricultural respiratory disease often goes untreated and unreported, especially by small operations not regulated by the Occupational Safety and Health Administration (OSHA), making it nearly impossible to determine the true extent of the problem (Kirkhorn\& Garry 2000; Ross et al. 2001).

All children are at risk for contact with environmental toxins, but the burden of toxic exposures is disproportionately allocated to poor ethnic minorities (Schell 1997; Moore 2003; Dilworth-Bart \& Moore 2006). "Economic factors not only constrain choices but also inequitably distribute human made stressors." and the psychosocial stress and environmental pollutants associated with poverty do not occur independently of one another. Rather, the effects may accumulate through risk focusing, a process by which exposures to toxic or infectious environmental materials are differentially allocated to a specific group partly because of previous exposure to those materials (Schell 1997; Yassin et al. 2002). 


\section{Pesticides poisonings}

Agro-chemical industry has offered thousands of compounds. The climatic condition of Pakistanfavors pest build up that destroys about 20 percent of potential agricultural crop. The health of the pesticides handlers and farmers in particular are at high risks due to irrational use of pesticides. Pesticides cause the acute and chronic health effects; organophosphate and carbamate groups are more important. These insecticides inhibit cholinesterase, an enzyme critical for normal functioning of the nervous system (Travisi\&Nijkamp 1998; Gelman\& Hill 2007; Soares\& Porto 2012).

\subsection{Prevalence of pesticides poisoning}

In USA, more than 18,000 products are licensed for use and each year more than 2 billion pounds of pesticides are applied to crops, gardens, in homes etc. (U.S EPA 2002). The major economic and environmental losses due to the application of pesticides in public health were 1.1 billion dollars per year in USA (Pimentel 2005). Such wide spread use results in pervasive human exposure. Evidence continues to accumulate that pesticide exposure is associated with impaired health. Occupational exposure is known to result in an annual incidence of 18 cases of pesticides related illness for every 100,000 workers in U.S (Calvert et al. 2004). Pesticide poisoning is a major public health problem in many developing countries (Xue et al. 1987; Jeyaratnam 1990). In developing world, pesticide poisoning causes more deaths than infectious diseases. Pesticide poisoning among farmers and occupational workers in developing countries is alarming (McCauley et al. 2006). WHO estimated approximately 20,000 workers die from exposure every year, the majority in developing countries (Pimentel et al. 1992; Kishi et al. 1995). The number of intoxications with organophosphates is estimated at some 3000,000 per year and the number of deaths and casualties some 300,000 per year (Peter 2003). Ahmed and co workers have reported 64 percent of fatal cases of acute pesticides poisoning in Multan, Pakistan occurred due to Ops pesticide spraying (Ahmad et al. 2002; Ahmed et al. 2006) However another study revealed 21 percent of occupational pesticides poisoning in hospitalized patient (Afzal et al. 2006).

\subsection{Acute toxicity}

Organophosphorous compound exert acute systemic toxicity by inhibiting the enzymes AChE through a process of phosphorylation. Pesticides bind to cholinesterase and block the hydrolysis of the acetylcholine and acetic acid at the post synaptic junctions without junctioning acetyl cholinesterase; acetylcholine accumulates (Chan \&Critchley 1998; Mason 2000). OPs induced neuronal symptoms are a consequence of axonal death. Following OPs exposures inhibition of neuronal enzymes, called neuropathy target esterase, occurs and many of them are irreversible. 


\section{Occupational health \& safety (OHS) (clinical recommendations)}

Health care providers are in an ideal position to identify and assess a patient's risk for exposure. The first step is to obtain an environmental history that covers residential and employment histories, types of work activities performed currently and in the relevant past, and possible sources of exposure to biological or chemical agents. For each exposure source identified, additional information needs to be collected, such as frequency, duration, and intensity. Women who are pregnant or planning a pregnancy, especially those currently performing farm work, should be informed of the implications of exposure before, during and after pregnancy, and assisted in making decisions that are appropriate for their individual work and home situations (McDiarmid\&Gehle (2006). In addition, providers should encourage mothers to avoid exposure that might contaminate breast milk without unduly alarming them, perhaps by associating it with the importance of not smoking or drinking alcohol during pregnancy and nursing (Pohl \&Tylenda 2000; Nickerson 2006). Of course, breast feeding should continue to be strongly encouraged since all evidence indicates that the known benefits far outweigh the potential risks (Eskenazi et al. 2006). Education about pesticide safety is an important measure for preventing exposure. The Migrant Clinicians Network has recently developed a 14-page full-color Spanish language comic book and Wake Forest University School of Medicine has produced patient education handouts and posters in English and Spanish. Women living in farm worker households should be offered additional education on ways they and the farm workers with which they live can reduce take-home exposure:

- remove work clothes and shoes before entering the home

- shower or bath upon returning home and before touching other people

- store and launder dirty work clothes separately from other clothing (Rao et al. 2006)

As the evidence continues to accumulate of the overall hazards that pesticides pose to human health, it is important that health care providers consider the possibility and consequences of occupational, dietary and residential exposure to pesticides for their female patients. Occupational exposure is almost certainly the primary source of exposure for farm workers and their families (McDiarmid\&Gehle 2006; WHO 2006). Awareness of the ways in which pesticide exposure occurs and the danger it poses are a crucial component of comprehensive preconception and prenatal care for farm worker women.

Most of the units are seriously concerned with workers health issues. Generally, they have their own OHS plans and policies, which they endeavour to, implement and follow. Following OHS issues, which require more attention are identified because without following these practices a proper assessment of the workers exposure cannot be made:

i. Most of the units are not carrying out the required monitoring of the working air quality, with respect to pesticides and solvents.

ii. Records of accidents and disease are not being properly maintained.

iii. iii. Many of the antidotes are not available readily in the market; this situation is not satisfactory to cope with emergency. 


\section{Local study}

In Egypt the information on the impact of pesticides on health aspects of farm workers and pesticides dealers is lacking and base-line information needs to be generated so that risk exposure of farming community may be minimized. Hence, this book chapter is planned to explain how pesticides are dangerous for humankind, animals and food products; as well to determine pesticide residues in blood and their correlation with biochemical markers for assessment of adverse health effects on farmers, market workers and spray workers as well as to assess the level of knowledge on precautions of pesticides safety.

\subsection{Materials and methods}

The study was conducted from July 2009 to June 2010 in seven villages (El-Mahmodia, Met Tarif, ElYosifia, Deiarb, El-Daraksa, Hamada and Ali Hendi) located in Dekrnes, Meniate ElNasr and Baniebad provinces, Dakahlyia governorate, north Egypt.

\section{Basic design and sample size}

Seventy healthy male individuals in age group of 30-55 year comprising of 30 farmers, 25 spray workers and 15 market workers were selected for the present study. The individuals selected had history of exposure to different classes of pesticides for 5 to 15 years. They were compared with 25 control individual residents of same area who had no history of pesticide exposure, either as farm worker or as pesticide dealer.

\section{Field survey}

All the individuals were provided a questionnaire seeking information on the types of pesticides they mostly used protective equipment or cloths during preparation and application of pesticides, concentrations recommended for pesticides use. In addition, the questionnaire elicited information about the re-entry period (the minimum amount of time that must pass between the times of application of pesticide and the time the farmers could go into the field without wearing personal protective equipment). The individuals selected included those who worked in both field crops and vegetables on the same ground but in different seasons.

\subsubsection{Hematological effects}

\section{a. Sample collection}

Fresh blood samples were collected from the arm vein $(10 \mathrm{ml})$. Each blood sample was divided into three tubes, the $1^{\text {st }}$ tube contained heparin for hematological assays. In the 2 tubes the blood sample was left for a short time to allow the blood to coagulate for biochemical analysis (aminotransferase (AST), Plasma alanine aminotransferase (ALT), acetyl cholinesterase (AChE), urea, creatinine and prothrombin time) and the $3^{\text {rd }}$ tube contained blood sample for determination of pesticide residues.

\section{b. Hematological analysis}


The blood in heparinised ampoules was analyzed for white blood cells (WBC), red blood cells (RBC), hemoglobin (Hb) and platelets (PLT) counts as per the method of Schalm (1986).

\subsubsection{Biochemical analysis}

Plasma was separated by centrifugation at $1500 \mathrm{rpm}$ for $15 \mathrm{~min}$. Serum enzymes and biochemical analysis were carried out by Medical Biochemistry Lab (Faculty of Medicine, MansouraUniversity, Mansoura, Egypt). Plasma alanine aminotransferase (ALT) and aspartate aminotransfersae (AST) activities were determined according to IFCC method Bergmeyer et al. (1998 a, b) while plasma acetyl cholinesterase (AChE) activity was measured as per Ellman's colorimetric method (Ellmann et al. 1961). Urea and creatinine concentrations were determined according to the methods of Sampson \& Baird (1979) and Spencer (1986), respectively. Prothrombin time (PT) was measured according to method described by Dacie\& Lewis (1984).

\subsubsection{Pesticide residue analysis}

\section{a. Extraction from blood serum}

Extraction of pesticide residues in the serum was as per the method of Rivas et al. (2001). Aliquots of $2.0 \mathrm{ml}$ serum samples of each individual and control were spiked separately by adding appropriate volumes of working standard solutions equilibrated for $3.0 \mathrm{~h}$ at room temperature in a test tube. Methanol $(1 \mathrm{ml})$ was sequentially added to $2.0 \mathrm{ml}$ sample by mixing in a rotary mixer for $1.0 \mathrm{~min}$, then $2.5 \mathrm{ml} \mathrm{n}$-hexane: diethyl ether $(1: 1 \mathrm{v} / \mathrm{v})$ was added. The solution was agitated and collected, and the aqueous phase extracted twice with $2.5 \mathrm{ml}$ n-hexane: diethyl ether $(1: 1 \mathrm{v} / \mathrm{v})$. The combined organic phases were evaporated and concentrated to $1.0 \mathrm{ml}$ in a graduated test-tube under a gentle stream of nitrogen.

\section{b. Clean-up}

Clean-up of the extract of pesticide residues in serum was performed according to the method of Mercedes et al. (2004). A florisil column of $200 \times 12 \mathrm{~mm}$ topped with anhydrous sodium sulfate was prepared and eluated with n-hexane. The extracts of each sample were passed twice through it. Eluate containing pesticides was evaporated and dried completely under a gentle stream of nitrogen. The samples were dissolved in $1.0 \mathrm{ml} n$-hexane and then injected into GLC and HPLC systems.

\section{c. Quantitative determination}

The whole cleaned up extracts of organphosphorus and pyrothroid residues were performed by GLC (Hewlett Packard 6890 series) equipped with electron capture detector (ECD) under the following conditions: column: HP-17 (30 $\mathrm{m} \times 0.32 \mathrm{~mm} \times 0.25 \mu \mathrm{m}$ film thickness), temperatures: column $240^{\circ} \mathrm{C}$; detector $350^{\circ} \mathrm{C}$ and injection $320^{\circ} \mathrm{C}$. The quantitative analysis of carbamate pesticide residues was performed by HPLC (Agilent 1100 Series with workstation). UV Diod-array detector set at $220 \mathrm{~nm}$ and the analytical column NucleosilC18, 5 um $(4 \times 250 \mathrm{~mm})$ was used. The mobile phase was acetonitrile-water at flow rate $1 \mathrm{ml}$ $\mathrm{min}^{-1}$. All solvents and chemicals used were of analytical grade free of interfering residues 
as tested by Gas chromatograph. The statistical significance of data was assessed by Duncan and Tukey tests at $\mathrm{p}<0.05$ and $\mathrm{p}<0.01$ (Snedecor\& Cochran 1980).

\subsection{Results}

\section{Field survey}

The most frequently used pesticides by the subjects in this study are shown in Table 1 . Inorganic compound, organophosphates, carbamates and pyrothrids are the most pesticides used in Egypt. Zinc phosphide was the most often used insecticide (97.14 \%) followed by chlorpyrifos and malathion (94.3\%). The study revealed that the majority of study subjects were not taking the necessary precautions to prevent hazards associated with their use (Tables 2 and 3). The results of survey revealed that 60.0, 6.7 and 12.0\% of farmers, market workers and spray workers did not wear protective apparels (such as overall, boots, gloves, etc.). While 16.7, 60.0 and $80.0 \%$ of farmers, market workers and spray workers, respectively, wear overall only 10.0, 20.0 and $84.0 \%$ wear special boots and $6.7,66.7$ and $24.0 \%$ farmers, market workers and spray workers, respectively, wear gloves. The farmers did not use mask while 26.7 and $24.0 \%$ of market and spray workers used masks. About 20 and $52 \%$ of farmers and spray workers use hats, but pesticides marketing did not use them.

The survey revealed that the most of subjects were washing themselves after pesticides operation (Table 3). Also 83.3 and $86.7 \%$ of farmers and market workers smoke or drink and eat food during mixing or applying pesticides, while about $40.0 \%$ of pesticide sprayers practice these habits. About $16.7 \%$ farmers and $20.0 \%$ pesticide spray workers do have knowledge on re-entry periods. Majority of farmers and pesticide spray workers do not bother to read the pesticide labels and contrarily $80 \%$ pesticide market workers read labels. Interestingly 20.0, 13.3 and $40.0 \%$ of farmers, market workers and spray workers, respectively, reported that they re-used the pesticide containers, while the majority of farmers and spray workers (80.0 and $60.0 \%$, respectively) leave it in the field after use.

\subsubsection{Hematological effects}

No significant differences were observed between RBC counts in pesticides-exposed subjects and control group (Table 4). However, a significant decrease in hemoglobin $[\mathrm{Hb}]$ level $(-12.1 \%)$ and platelet count $(-6.6 \%$ below control level) was observed in pesticide-sprayer group. On contrary, a significant increase in WBC counts was noticed in pesticides market and spray workers groups (34.6 and $73.9 \%$ above the control level, respectively) as compared with control.

\subsubsection{Biochemical effects}

A slight insignificant increase was observed in AST and ALT activities in all the subjects (Table 5). Higher level of both these enzymes was observed in pesticide sprayers (8.41 and $34.41 \%$ above the control level, respectively). A significant decrease in AChE activity was observed in pesticide-exposed groups in comparison to control. High inhibition rate 
was observed in spray workers followed by market workers (-48.7 and $-41.5 \%$, respectively). On the contrary, a significant rise in urea concentration was noticed in spray workers $(+50.0 \%)$, but no significant differences were observed in creatinine concentration. This study revealed a positive correlation between pesticides exposed with prothrombin time (PT). PT was significantly raised among the farmers, market workers and spray workers (12.0, 23.5 and 44.7\% above the normal level, respectively).

\begin{tabular}{|c|c|c|c|c|}
\hline Pesticide & Group & $\begin{array}{c}\text { WHO } \\
\text { category }\end{array}$ & Type of use & $\%$ * \\
\hline Zinc phosphide & Inorganic compound & $\mathrm{IB}$ & Rodenticide & 97.14 \\
\hline Chlorpyrifos & Organophosphorus & ॥ & Insecticide & 94.3 \\
\hline Malathion & Organophosphorus & III & Insecticide & 94.3 \\
\hline Carbofuran & Carbamate & $\|$ & Nematicide & 90.0 \\
\hline Abamectin & Avermectin & $\mathrm{IB}$ & Acricide & 80.0 \\
\hline Lufenuron & Benzoylurea & $U$ & IGR & 80.0 \\
\hline Copper hydroxide & Inorganic compound & III & Fungicide & 78.57 \\
\hline Lambdacyhalothrin & Pyrothrid & $\|$ & Insecticide & 71.42 \\
\hline Profenofos & Organophosphorus & $\|$ & Insecticide & 71.42 \\
\hline Mancozeb & Thiocarbamate & $U$ & Fungicide & 67.14 \\
\hline Brominal & Hydroxybenzonitrile & ॥ & Herbicide & 64.3 \\
\hline Pirimicarb & Carbamate & $\|$ & Insecticide & 62.86 \\
\hline Fenpyroximate & Fenpyroximate & ॥ & Acricide & 61.42 \\
\hline Clodinafop - propargyl & Aryloxyphenoxypropionate & III & Herbicide & 61.4 \\
\hline Maneb & Thiocarbamate & U & Fungicide & 58.57 \\
\hline Chlorpyrifos-methyl & Organophosphorus & $\|$ & Insecticide & 57.14 \\
\hline Thiobencarb & Thiocarbamate & $\|$ & Herbicide & 57.1 \\
\hline Diflubenzuron (IGR) & Benzoylurea & $U$ & IGR & 54.29 \\
\hline Dicofol & Organochlorine & III & Acricide & 54.29 \\
\hline Dimethoate & Organophosphorus Juvenile & $\|$ & Insecticide & 50.0 \\
\hline Pyriproxyfen & hormone mimic & $U$ & IGR & 44.29 \\
\hline Methomyl & Carbamate & IB & Insecticide & 42.86 \\
\hline Fluazifop-o-butyl & Aryloxyphenoxypropionate & $U$ & Herbicide & 42.9 \\
\hline Glyphosate & Glyphosate-diammonium & $U$ & Herbicide & 35.7 \\
\hline Fenvalerate & Pyrothrid & $\|$ & Insecticide & 32.86 \\
\hline Thiamethoxam & Neonicotinoid & III & Insecticide & 28.57 \\
\hline Acetamiprid & Neonicotinoid & $\|$ & Insecticide & 25.71 \\
\hline Triazophos & Organophosphorus & IB & Insecticide & 25.71 \\
\hline Alpha-cypermethrin & Pyrothrid & $\|$ & Insecticide & 24.29 \\
\hline
\end{tabular}

*Source: WHO (2005) classification: Ib = Highly hazardous, II = Moderately hazardous, III = Slightly hazardous, U = Unlikely to pose acute hazard in normal use. $* \%=$ Percent of most frequently by subjects.

Table 1. Pesticides frequently used by the subjects in this study 


\begin{tabular}{ccccc}
\hline $\begin{array}{c}\text { Precautions equipment } \\
\text { Wear overall }\end{array}$ & $\begin{array}{c}\text { Farmers } \\
\mathbf{( \% )}\end{array}$ & $\begin{array}{c}\text { Pesticide- market workers } \\
\mathbf{( \% )}\end{array}$ & $\begin{array}{c}\text { Pesticide-spray workers } \\
\mathbf{( \% )}\end{array}$ & $\begin{array}{c}\text { Mean } \\
(\%)\end{array}$ \\
\hline Special boots & 16.7 & 60.0 & 80.0 & 48.57 \\
\hline Gloves & 10.0 & 20.0 & 84.0 & 25.70 \\
\hline Mask & 6.7 & 66.7 & 24.0 & 25.70 \\
\hline Wide hat & 0.0 & 26.7 & 24.0 & 14.29 \\
\hline
\end{tabular}

Table 2. The response of farmers, pesticide marketing and spray workers regarding wearing of protective equipment

\begin{tabular}{ccccc}
\hline Precautions & Farmers(\%) & Market workers(\%) & $\begin{array}{c}\text { Spray } \\
\text { workers(\%) }\end{array}$ & Mean(\%) \\
\hline Wash after pesticide operation & 66.7 & 93.3 & 88.0 & 80.00 \\
\hline Smoke, drink and eating food & 83.3 & 86.7 & 40.0 & 60.57 \\
\hline Re-entry period & 16.7 & 0.0 & 20.0 & 41.43 \\
\hline Read pesticide labels & 36.7 & 80.0 & 24.0 & 25.70 \\
\hline Re-use pesticide containers & 20.0 & 13.3 & 12.0 & 14.29 \\
\hline Didn't follow precautions & 16.7 & 6.7 & 12.0 \\
\hline
\end{tabular}

Table 3. The response of farmers, pesticide market and spray workers regarding practices on safety measures during pesticide operations

\begin{tabular}{|c|c|c|c|c|}
\hline Treatments & $\operatorname{RBCs}\left(10^{6}\right)$ & HGB (mg) & Platelets $\left(10^{3}\right)$ & WBCs $\left(10^{3}\right)$ \\
\hline Control & $5.02 \mathrm{a}$ & $13.74 \mathrm{a}$ & $299.0 \mathrm{a}$ & $4.68 c$ \\
\hline Farmers & 4.83 a $(-3.78)^{\star}$ & $14.04 \mathrm{a}(+2.18)$ & $240.2 \mathrm{ab}(-19.67)$ & 4.66 c $(-0.43)$ \\
\hline Market workers & 4.7 a $(-6.37)$ & $13.42 \mathrm{a}(-2.33)$ & $263.4 \mathrm{ab}(-11.91)$ & $6.3 b(+34.6)$ \\
\hline Spray workers & 4.68 a (-6.77) & $12.08 b(-12.08)$ & 159.6 b (-46.62) & 8.14 a (+73.93) \\
\hline LSD $5 \%$ & 0.844 & 1.30 & 103.89 & 1.121 \\
\hline
\end{tabular}

The figures superscripted with same alphabets in the same column do not significantly differ from each other as per Duncan test.

*The values in parenthesis are the percent content in comparison to the respective control.

Table 4. Effect of pesticide residues on hematological parameters of farmers, pesticide market and spray workers 


\begin{tabular}{|c|c|c|c|c|c|c|}
\hline Treatments & $\mathrm{AST}\left(\mathrm{u} / \mathrm{ml}^{-1}\right)$ & $\operatorname{ALT}\left(\mathrm{u} / \mathrm{ml}^{-1}\right)$ & $\operatorname{AchE}\left(\mathrm{u} / \mathrm{ml}^{-1}\right)$ & $\begin{array}{l}\text { Urea(mg / } \\
\left.\mathrm{dl}^{-1}\right)\end{array}$ & $\begin{array}{l}\text { Creatinine }(\mathrm{m} \\
\left.\mathrm{g} / \mathrm{dl}^{-1}\right)\end{array}$ & $\begin{array}{l}\text { Prothrombin } \\
\text { Time (second) }\end{array}$ \\
\hline Control & $21.4 a$ & $18.6 \mathrm{a}$ & 1874.6a & 28.8 bc & $1.25 \mathrm{a}$ & $10.96 d$ \\
\hline Farmers & $21.8 \mathrm{a}(+1.8)$ * & $22.4 \mathrm{a}(+20.43)$ & $1573.4 b(-16.1)$ & $23.4 c(-18.75)$ & $1.12 \mathrm{a}(-10.4)$ & $12.28 c(+12.0)$ \\
\hline $\begin{array}{l}\text { Market - } \\
\text { workers }\end{array}$ & $23.2 \mathrm{a}(+8.41)$ & $22.6 \mathrm{a}(+21.51)$ & $1096.2 c(-41.5)$ & $36.8 \mathrm{ab}(+27.8)$ & $1.21 \mathrm{a}(-3.2)$ & $13.54 \mathrm{~b}(+23.54)$ \\
\hline Spray - workers & $23.2 \mathrm{a}(+8.4)$ & $25.6 \mathrm{a}(+34.4)$ & $962.0 c(-48.7)$ & $43.2 \mathrm{a}(+50.0)$ & $1.33 \mathrm{a}(+6.4)$ & $15.86 a(+44.7)$ \\
\hline $\mathrm{LSD}_{0.005}$ & 11.2 & 14.76 & 165.11 & 12.72 & 0.298 & 0.99 \\
\hline \multicolumn{7}{|c|}{$\begin{array}{l}\text { The figures superscripted with same alphabets in the same column do not significantly differ from each other as pe } \\
\text { Duncan test. }\end{array}$} \\
\hline
\end{tabular}

Table 5. Effect of pesticide residues on biochemical parameters of farmers, pesticide market and spray workers

\subsubsection{Pesticide residues}

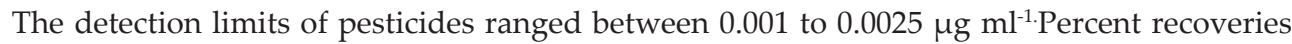
in reference samples were $82-93 \%$. Accordingly, the sample analysis data was corrected for these recoveries. About 76.7, 92.5 and $100 \%$ of farmers, market workers and spray workers had varied levels of insecticide residues in their blood (Table 6). About 60.0 and $23.3 \%$ of farmers had chlorpyrifos and lambada-cyhalothrine (0.022 and $\left.0.014 \mathrm{mg} \mathrm{kg}^{-1}\right)$ residues above the acceptable daily intake (ADI) in their blood. In addition, most of the pesticides market workers were observed to have multiple pesticide residues above ADI. About $80.0 \%$ of them had carbofuran residues and $73.3 \%$ had chlorpyrifos $\left(0.217\right.$ and $\left.0.137 \mathrm{mg} \mathrm{kg}^{-1}\right)$. All pesticides spray workers had high amount of residues detected in their blood; most of them had chlorpyrifos $(84.0 \%)$, profenofos $(72.0 \%)$, lambda-cyhalothrine $(64.0 \%)$, pirimicarb $(52.0 \%)$, carbofuran $(28.0 \%)$ and triaziphos $(24.0 \%)$ residues above the recommended ADI levels because of their extensive use. Further, about 23.3 and $7.5 \%$ of farmers and market workers, respectively, had no insecticide residues in their blood.

\subsection{Discussion}

The present study was carried out in some villages located in Dakahlyia Governorate, Egypt, where infestation level of pests is very high. Ever growing demand for enhancing crop production to meet the requirements of increasing population and the need to enhance farm income tends farmers to use pesticides excessively and irresponsibly. The major pesticides used $(58.62 \%)$ by the farmers, market workers and spray workers in the study area include zinc phosphide, chlorpyrifos, malathion, carbofuran, abamectin, lufenuron and copper hydroxide. As per WHO (2005) most of pesticides used are classifies either highly or moderately hazardous.

Interviews showed that the majority of farmers and pesticide spray workers do not take the necessary precautionary measures to prevent hazards associated with their use. Also, the 
low-level education of study groups coupled with lack of good training of pesticides resulted in high exposure hazards (Tijani 2006; Damals et al. 2006). Similar results were obtained by Tchounwou et al. (2002) who reported that in Menia El-Kamh in Sharkia Governorate (Egypt) more than $95 \%$ of farm workers do not practice safety precautions during pesticide formulation and application.

\begin{tabular}{|c|c|c|c|c|c|c|c|c|c|c|}
\hline \multirow[t]{2}{*}{ Pesticides } & \multirow{2}{*}{$\begin{array}{c}\mathrm{ADI} \text { * } \\
(\mathrm{mg} / \mathrm{kg} \\
\text { b.w **) }\end{array}$} & \multicolumn{3}{|c|}{ Farmers } & \multicolumn{3}{|c|}{ Pesticides market workers } & \multicolumn{3}{|c|}{ Pesticide spray workers } \\
\hline & & $\%$ & $\begin{array}{l}\text { Range } \\
\mathrm{mg} / \mathrm{kg}\end{array}$ & $\begin{array}{l}\text { Average } \\
\mathrm{mg} / \mathrm{kg}\end{array}$ & $\%$ & $\begin{array}{l}\text { Range } \\
\mathrm{mg} / \mathrm{kg}\end{array}$ & $\begin{array}{l}\text { Average } \\
\mathrm{mg} / \mathrm{kg}\end{array}$ & $\%$ & $\begin{array}{l}\text { Range } \\
\mathrm{mg} / \mathrm{kg}\end{array}$ & $\begin{array}{l}\text { Average } \\
\mathrm{mg} / \mathrm{kg}\end{array}$ \\
\hline Chloropyrifos & 0.01 & 60.0 & $0.07-0.34$ & 0.022 & 73.3 & $0.1-2.08$ & 0.137 & 84.0 & $0.31-3.76$ & 0.247 \\
\hline Malathion & 0.3 & 33.3 & $0.009-0.26$ & 0.016 & 53.3 & 0.091 .78 & 0.097 & 72.0 & $0.16-2.44$ & 0.183 \\
\hline Profenofos & 0.01 & 36.7 & $0.03-0.178$ & 0.008 & 53.3 & $0.3-1.67$ & 0.088 & 72.0 & $0.26-2.67$ & 0.208 \\
\hline Pirimicarb & 0.02 & 40.0 & $0.007-0.09$ & 0.004 & 33.3 & $0.05-0.95$ & 0.034 & 52.0 & $0.47-1.8$ & 0.117 \\
\hline Carbofuran & 0.02 & 26.7 & $0.006-0.04$ & 0.009 & 80.0 & $0.14-2.6$ & 0.217 & 28.0 & $0.07-0.49$ & 0.026 \\
\hline Lambdacyhalothrin & 0.005 & 23.3 & $0.05-0.17$ & 0.014 & 40.0 & $0.07-0.53$ & 0.046 & 64.0 & $1.08-2.11$ & 0.136 \\
\hline Methomyl & 0.03 & 0.0 & N.D *** & N.D & 26.7 & $0.04-0.09$ & 0.007 & 32.0 & $0.36-0.97$ & 0.067 \\
\hline Triazophos & 0.001 & 3.3 & 0.001 & 0.001 & 0.0 & N.D & N.D & 24.0 & $0.0005-0.004$ & 0.002 \\
\hline Dimethoate & 0.002 & 0.0 & N.D & N.D & 6.67 & 0.001 & 0.001 & 12.0 & $0.0007-0.0017$ & 0.001 \\
\hline Fenvalerate & 0.02 & 0.0 & N.D & N.D & 0.0 & N.D & N.D & 12.0 & $0.004-0.01$ & 0.008 \\
\hline \multicolumn{2}{|c|}{ Persons having no residues } & \multicolumn{3}{|c|}{23.3} & \multicolumn{3}{|c|}{7.5} & \multicolumn{3}{|c|}{0.0} \\
\hline
\end{tabular}

Table 6. The percent of farm workers, pesticide-market workers and pesticide-spray workers having different pesticide residues and mean concentration of residues ( $\mathrm{mg} \mathrm{kg}^{-1} \mathrm{~b} . \mathrm{w}$.) in their blood

Our studies revealed significant changes in HGB level and platelets counts in pesticide spray workers and WBC counts in market workers and spray workers. The results are in agreement with Amr et al. 1997; Amr (1999), Abu Mourad (2005) and Al-Sarar et al. (2009) who reported that occupational exposure to pesticides resulted in alterations of hematological parameters. The increase in ALT and AST activities are good indicators of hepatic toxicity (Hall, 2001). The present study showed that insignificant elevation in liver functions (AST and ALT levels) of all study subjects. Similar observations have been made by Al-Sarar et al. (2009). Nevertheless, significant increase in the levels of these enzymes was seen in occupationally exposed workers (Tomei et al. 1998; Khan et al. 2008, 2009, 2010); and in sprayers of grape gardens in India (Patil et al. 2003). Plasma AChE activity has been used for several years as indicator to estimate the risks associated with pesticides induced toxicity in occupationally exposed workers (Dasgupta et al. 2007; Khan et al. 2008; Shalaby\&Abd El-Mageed 2010). Present study revealed a negative correlation between pesticide residues with AChE activity. We found significant inhibition in its activity in exposed subjects than that of the control. High inhibition rate was observed in pesticide spray workers followed by market workers thereby indicating that the study subjects had pesticide residues in their blood especially organophosphorus and 
carbamate compounds. Similar results were noticed among the cotton growers in India (Mancini et al. 2005); in Palestinian farm workers (Abu Mourad 2005) and the tobacco farmers in Pakistan (Khan et al. 2008). In orchard farmers of Kashmir about $31.9 \%$ patients (124 out of 389) were orchard-farm workers and the orchard residents and orchard playing children had higher serum cholinesterase (<6334 U/l) level (Bhat et al. 2010).

In present study there was significant increase in urea concentration in pesticide sprayers, with no significant changes in creatinine level in all cases. Some previous studies have shown subtle nephrotoxic changes in workers occupationally exposed to pesticides with higher levels of creatinine and urea (Attia 2006; Shalaby 2006; Khan et al. 2008). Nevertheless, Al-Sarar et al. (2009) observed insignificant elevated levels of serum urea and creatinine among pesticide sprayers of RiyadhMunicipality, Kingdom of Saudi Arabia. In addition, this study revealed significant increase in prothrombin time (PT) in all cases studied. In general, this noticeable effect of pesticide upon blood coagulation could be attributed to the great defect in blood coagulability and to the severe damage of capillaries (Clarke \& Clarke 1978; Leck\& Park 1981).

Pesticide residues in blood are likely to appear at very low concentrations because as soon as it enters into the body most of the chemical may be metabolized and the metabolites may accumulate to induce toxic effect (Soomro et al. 2008). However, the ultra low quantities of contaminants present in body indicate toxicological impact on exposed population. Present results revealed that all pesticide spray workers had insecticide residues in their blood; however, 23.3 and $7.5 \%$ farmers and pesticides marketing workers did not have residues. In addition, the amounts of these residues are high in spray workers than its values in other groups, but these amounts are very low in farmers. The spray workers during spray on crops are directly exposed to pesticides while mixing, handling, spraying as well as through contaminated soil, air, drinking water, eating food and smoking at work places. Also, pesticides market workers are directly exposed to pesticides while handling and opening of pesticide containers in pesticide stores, but farmers are working in the field after pesticides operation. In our study, most of subjects had multiple pesticide residues above the ADI in their blood, which is injurious to health. Most of them had chlorpyrifos, profenofos, carbofuran and lambda-cyhalothrin residues. Similar results were obtained by Coye et al. (1986) and Khan et al. (2008) who reported that the tobacco farmers had multiple pesticide residues above ADI in their blood consisting of $63 \%$ methomyl; $56 \%$ thiodicarb; $62 \%$ cypermethrin; $49 \%$ imidaclprid; $32 \%$ methamidophos and $27 \%$ had endosulfan residues. Sosan et al. (2008) has reported that 42 out of 76 cacao farmers had residues of diazinon, endosulfan, propoxur and lindine in their blood. Similarly Bhat et al.(2010) has reported that $90.04 \%$ brain tumour patients (389 out of 432) in Kashmir were orchard farmers exposed to high levels of multiple types of neurotoxic and carcinogenic pesticides for more than 10-20 years.

Generally, controlled studies have shown mixed results about chemical insecticides and chemical fertilizers. We are looking for a solution for the actual problem with intensive insecticide uses. Some support the conclusion that organic production methods lead to increases in nutrients. Other studies show no demonstrable differences. A recent analysis conducted by the LondonSchool of Hygiene \& Tropical Medicine provides a comprehensive 
review of the available literature (Dangour et al. 2009). The authors identified 46 studies with sufficient documentation and quality upon which they performed a systematic review. Eleven nutritional categories were evaluated. The nitrogen content of conventionally-grown plants was higher, and the phosphorus and titratable acidity levels were higher for organically-grown plants. These differences were considered biologically plausible due to differences in fertilizer use (nitrogen and phosphorus) and ripeness at harvest (titratable acidity). There was no difference for the remaining eight categories, including some key ones, including Vitamin C, phenolic compounds, magnesium, calcium, potassium, zinc, total soluble solids, and copper.

\section{Conclusion}

The present study revealed that most of persons studied did not take necessary precautionary measures to avoid the hazards associated with pesticides marketing, handling and application. Analysis showed that low level of education of users and lack of proper training about safe pesticide usages and handling resulted in high occupational hazards. Most of individuals studied had multiple pesticide residues above ADI in their blood which is injurious to health. The study suggests promotion of awareness among pesticide-users with right practices for safe use and handling of pesticides. Pesticides are absorbed by inhalation, ingestion and/or dermal contact so pesticide users should wear protective clothing. Also, they are highly advised to read pesticide labels before use. The role of government regulations and agriculture experiment services as well as the cooperation of pesticide manufactures of is vital in reducing the risks and hazards of pesticides.

\section{Acknowledgements}

Authors are thankful to Dr. Mustafa Neamat Allah, Assistant Professor, Faculty of Medicine, MansouraUniversity, for his immense support during this study. Also, we thank Dr. ElSayed Ibrahim El-Sayed, Professor of Pesticides, National Research Centre, Egypt, for his assistance in preparation of this book chapter.

\section{Author details}

Nabil El-Wakeil ${ }^{1,3 *}$, Shehata Shalaby ${ }^{1}$, Gehan Abdou ${ }^{1}$ and Ahmed Sallam ${ }^{2}$

*Address all correspondence to: nabil.el-wakeil@landw.uni-halle.de

1 Pests \& Plant Protection Dept. National Research Centre, Dokki, Cairo, Egypt

2 Plant Protection Dept. Faculty of Agriculture, SohagUniversity, Sohag, Egypt 
3 Institute of Agric. \& Nutritional Sciences, Martin Luther-University Halle-Wittenberg, Germany

\section{References}

[1] Abu Mourad T (2005) Adverse impact of insecticides on the health of Palestinian farm workers in the Gaza Strip: A hematologic biomarkers study. Internat J Occup $\mathcal{E}$ Environ Health 11:144-149.

[2] Afzal S, Ahmad M, Mubarik A, Saeed F, Rafi, Sh, Saleem N \&Qureshi AH (2006) Acute organophosphorus poisoning-an experience. Pak Armed Forces Med J 56:150-156.

[3] Ahmad R, Ahad K, Iqbal R \& Muhammad A (2002) Acute poisoning due to commercial pesticides in Multan. Pak J Med Sci 18:227-231.

[4] Ahmed M, Verma S, Kumar A\&Sidiqui MKJ (2006) Delta-aminolevulinic acid dehydratase inhibition and oxidative stress in relation to blood lead among urban adolescent. Hum ExperiToxicol 25:547-553.

[5] Ajayi OC \&Akinnifesi FK (2008) Farmers' understanding of pesticide safety labels and field spraying practices: a case study of cotton farmers in northern Cote d'Ivoire. Sci Res Essays 2:204-210.

[6] Aldridge JE, Meyer A, Seidler FJ \&Slotkin T (2005) Alteration in central nervous system serotonergic and dopaminergic synaptive activity in adulthood after prenatal or neonatal chlorpyrifos exposure. Environ Health Perspect 113:1027 - 1031.

[7] Al-Sarar AS, Abo Bake Y, Al-Erimah GS, Hussein HI \&Bayoumi AE (2009) Hematological and biochemical alterations in occupationally pesticides-exposed workers of Riyadh Municipality, Kingdom of Saudi Arabia. Res J Environ Toxicol 1:1-7.

[8] Amr MM (1999) Pesticide monitoring and its health problems in Egypt, a third world country.Toxicological Letters 107:1-3.

[9] Amr MM, Halim ZS \&Moussa SS (1997) Psychiatric disorders among Egyptian pesticides applicators and formulators. Environ Res 73:193-199.

[10] Arcury TA, Quandt SA, Austin CK, Saavedra RM, Rao P\& Cabrera LF (2000) Preventing Agricultural Chemical Exposure: A Safety Program Manual Participatory Education With Farmworkers in Pesticide Safety. Department of Family and Community Medicine, WakeForestUniversitySchool of Medicine, Winston-Salem, NC.

[11] Atreya K (2008) Health costs from short-term exposure to pesticides in Nepal. SocSci Med 67:511-519.

[12] Attia MA (2006) Risk assessment of occupational exposure to pesticides.Earth Environ Sci 3:349-362. 
[13] Azmi MA, Naqvi SH \&Aslam M (2006) Effect of pesticide residues on health and different enzyme levels in the blood of farm workers from Gadap (rural area) Karachi, Pakistan. Chemosphere 64:1739-1744.

[14] Barthel E (1981) Increased risk of lung cancer in pesticide-exposed male agricultural workers. J Toxicol Environ Health 8:1027-1040.

[15] Bergmeyer HU, Herd MR \&Rej R (1998a) Approved recommendation 1985 on IFCC methods for the measurement of catalytic concentration of enzymes Part 3: IFCC method for alanine aminotransferase. J Clinic ChemE Clinic Biochem 24:481-489.

[16] Bergmeyer HU, Herd MR \&Rej R (1998b) Approved recommendation 1985 on IFCC methods for the measurement of catalytic concentration of enzymes Part 2: IFCC method for aspirate aminotransferase. J Clinic ChemE Clinic Biochem 24:49-55.

[17] Bhat A, Wani MA, Kirmani AR \&Raina TH (2010) Pesticides and brain cancer linked in orchard farmers of Kashmir. Indian J Med EPediatricOncol 31:110-120.

[18] BrownSK, Ames RG \&Mengle DC (1989) Occupational illness from cholinesterase inhibiting pesticides among agriculture pesticide applicators in California. Arch Environ Health 44:34.

[19] Calvert GM, Plate DK, Das R, Rosales R, Shafey O \& Thomsen C (2004) Acute occupational pesticide-related illness in the U.S. 1998-1999: Surveillance findings form the SENSOR-pesticides Program. Am J Ind Med 45:14-23.

[20] Carr SJ (1989) Technology for small-scale farmers in Sub-Saharan Africa: Experience with food crop production in five major ecological zones. Technical Papers, (109) World Bank: Washington, DC.

[21] Carroll D, Samardick RM, Bernard S, Gabbard S \& Hernandez T (2005) Findings from the National Agricultural Workers Survey (NAWS) 2001 - 2002: A Demographic and Employment Profile of United States Farm Workers. 9. Washington, DC, US Department of Labor.

[22] Chalermphol J \&Shivakoti GP (2009) Pesticide use and prevention practices of tangerine growers in northern Thailand. J AgrEduc Ext 15:21-38.

[23] Chan TYK \&Critchley JAJH (1998) Insecticides poisoning with Organophosphates and carbamates.Hong KongPractioner 20:604-613.

[24] Clarke EGC \& Clarke ML (1978) Veterinary Toxicology (ELBS edn.), MacMillan Publishing Co. Inc., New York, USA.

[25] Cohn BA, Wolff MS, Cirillo PM \&SholtzRI (2007) DDT and breast cancer in young women: new date on the significance of age at exposure. Environ Health Perspect115:1406-1414.

[26] Coronado GD, Thompson B, Strong L, Griffith WC \& Islas I (2004) Agricultural task and exposure to organophosphate pesticides among farm workers. Environ Health 112:142-147. 
[27] Coronado GD, Vigoren EM, Thompson B, Griffith WC \&Faustman EM (2006) Organophosphate pesticide exposure and work in pome fruit: Evidence for the take-home pesticide pathway. Environ Health Perspect114:999-1006.

[28] Coye MJ, Lowe JA \&Maddy KJ (1986) Biological monitoring of agricultural workers exposed to pesticides II: Monitoring of intact pesticides and their metabolites. J Occup Med 28:628-636.

[29] Curl CL, Fenske RA, Kissel JC, Shirai JH, Moate TF, Griffith W, Coronado G \& Thompson B (2002) Evaluation of take-home organophosphorus pesticide exposure among agricultural workers and their children. Environ Health Perspect 110:A787A792.

[30] Dacie JV \& Lewis SM (1984) Practical Hematology (6 ${ }^{\text {th }}$ ed). Churchill Livingstone, Edinburgh,London, UK.

[31] DamalasCA, Georgiou EB, Theodorou MG (2006a) Pesticide use and safety practices among Greek tobacco farmers: A survey. Int J Environ Health Res 16:339- 348..

[32] Damalas CA \&Hashemi SM (2010) Pesticide risk perception and use of personal protective equipment among young and old cotton growers in northern Greece. Agrociencia44:44: 363-371.

[33] DamalasCA, Theodorou MG \& Georgiou EB (2006b) Attitudes towards pesticide labelling among Greek tobacco farmers.Int J Pest Manag 52:269-274.

[34] Dangour AD, Dodhia SK, Hayter A, Allen E, Lock K \&Uauy R (2009) Nutritional quality of organic foods: a systematic review. Am J Clinic Nut 90:680- 685.

[35] Dasgupta S, Meisner C, Wheeler D, Xuyen K \&Thi Lam N (2007) Pesticide poisoning of farm workers - Implications of blood test results from Vietnam. Internat J Hygiene E Environ Health 210:121-132.

[36] Dilworth-Bart JE \& Moore CF (2006) Mercy mercy me: Social injustice and the prevention of environmental pollutant exposures among ethnic minority and poor children. Child Development 77:247-265.

[37] Ellmann GL, Courney KD, Andres V \& Featherstone RM (1961) A new and rapid colorimetric determination of acetylcholinesterase activity.BiochemPharmacol 7:75-88.

[38] El-WakeilNE, Sallam AAA \&Volkmar C (2009) Ecological studies on frit fly Oscinella frit (L.) and its control in summer wheat in Central Germany. Mitt Deut Gesell Allge EAngeEntomol 17:215-220.

[39] Eskenazi B, Marks AR, Bradman A, Fenster L, Johnson C, Barr DB \& Jewell NP (2006) In utero exposure to dichlorodiphenyltrichloroethane (DDT) and dichlorodiphenyldichloroethylene (DDE) and neurodevelopment among young Mexican American children. Pediatrics118(1):233-241.

[40] FAO (1986) Food and agricultural organization of the United Nation.Internat code of conduct on the distribution and use of pesticides, Rome. 
[41] FDA (2005) Food and Drug Administration Pesticide Program: Residue Monitoring 2003. Washington, DC, US Food \& Drug Administration, Center for Food Safety \& Applied Nutrition.

[42] Fenske RA, Lu CS, Simcox NJ, Loewenherz C, Touchstone J, Moate TF, Allen EH \&Kissel JC (2000) Strategies for assessing children's organophosphorus pesticide exposures in agricultural communities. J Expos AnalyE Environ Epidemiol10:662-671.

[43] Garry VF (2004) Pesticides and children.ToxicolEApplPharmacol198:152.

[44] Gelman A \& Hill J (2007) Data analysis using regression and multilevel/hierarchical models.Cambridge: CambridgeUniversity Press.

[45] Gurunathan S, Robson M, Freeman N, Buckley B, Roy A, Meyer R, Bukowski J \&Lioy PJ (1998) Accumulation of Chlorpyrifos on residential surfaces and toys accessible to children. Environ Health Perspect106:9-16.

[46] Hall R (2001) Principles of clinical pathology for toxicology studies. In: Principles and Methods of Toxicology. (ed. Hayes AW). Taylor and Francis,Philadelphia, USA.

[47] Hashmi I \&Dilshad KA (2011) Adverse Health Effects of Pesticides Exposure in Agricultural and Industrial Workers of Developing Country. Pesticides- The Impacts of Pesticides Exposure.ISBN: 978-953-307-531-0Intech Publisher, Margarita Stoytcheva (ed.) pp. 155-178.

[48] Hashemi SM, Mokhtarnia M, Erbaugh JM \&Asadi A (2008) Potential of extension workshops to change farmers' knowledge and awareness of IPM. SciTotal Environ 407: 84-88.

[49] Hayes TB, Case P, Chui S, Chung D, Haeffele C, Haston K, Lee M, Mai VP, Marjuoa Y, Parker J \&Tsui M (2006) Pesticide mixtures, endocrine disruption, and amphibian declines: Are we underestimating the impact? Environ Health Perspect114:40-50.

[50] Hernandez AF, Gomez M, Penan AG, Fernandez G, Lourdes R, Villanueva E \& Antonio P (2004) Effect of long term exposure to pesticides on plasma esterases from plastic green house workers. J Toxicol Environ Health Part A 67:1095-1108.

[51] Hernandez FA, Gomez MA, Perez VG, Lario VJ, Pena G \& Gill F (2006) Influence of exposure to pesticides on serum components and enzyme activities of cytotoxicity among intensive agricultural farmers. Environ Res 102:70-76.

[52] Hurtig AK, Sebastian MS, Soto A, Shingre A, Zambrano D \& Guerrero W (2003) Pesticide use among farmers in the Amazon Basin of Ecuador. Arch Environ Health 58:223-228.

[53] Ibitayo OO (2006) Egyptian farmers' attitudes and behaviors regarding agricultural pesticides: Implications for pesticide risk communication. Risk Anal 26:989-995.

[54] Icenogle LM, Christopher NC, Blackwelder WP, Caldwell DP, Qiao D, Seidler FJ, et al. (2004) Behavioral alterations in adolescent and adult rats caused by a brief subtoxic exposure to chlorpyrifos during neurulation. NeurotoxicolETeratol 26:95 - 101. 
[55] Jeyaratnam J (1990) Acute pesticide poisoning: A major global health problem. World Health Statistic Quarterly 43:139-144.

[56] Jurewicz J, Hanke W, Johansson C, Lundquist C, Ceccatelli S, Van Den Hazel P, Saunders M \&Zetterström R (2006) Adverse health effects of children's exposure to pesticides: What do we really know and what can be done about it. ActaPædiatrica95 (Suppl 453):71-80.

[57] Karabay NU, Cakmak B, Saym F \&Oguz MG (2004) Risk assessment of organophosphate pesticide exposure on greenhouse workers in Menderes Region, Develi Village (Turkey). T Klin Tip Bilimleri24:6-11.

[58] Karalliede L \&Senanayake N (1999) Organophosphate insecticide poisoning.J Internat Fed Clinic Chem 11:1.

[59] Khan DA, Bhatti MM, Khan FA, Naqvi ST \&Karam A (2008) Adverse effects of pesticides residues on biochemical markers in Pakistani tobacco farmers. Internat J Clinic Exp Med 1:274-282.

[60] Khan DA, Hashmi I, Mahjabeen W \&Naqvi TA (2009) Monitoring health implications of pesticide exposure in factory workers in Pakistan. Environ Monit Assess 168:231-240.

[61] Khan DA, Saira S, Mahwish MB, Farooq AK \&Naqvi TA (2010) Risk assessment of pesticide exposure on health of Pakistani tobacco farmers. J Expo SciE Environ Epidemiol 20: 196-204.

[62] Kirkhorn SR \& Garry VF (2000) Agricultural lung diseases.Environ Health Perspect108:705-712.

[63] Kishi M, Hirschhorn N, Ojajadisastra M, Satterfee LN, Stroman S \&Dilts R (1995) Relationship of pesticide spraying to signs and symptom in Indonesian farmers. Scand J Environ Health 21:124-133.

[64] Konradsen F, Van der Hoek W, Cole DC, Hutchinson G, Daisley H, Singh S, Eddleston $M$ (2003) Reducing acute poisoning in developing countries-options for restricting the availability of pesticides. Toxicology 192:249-261.

[65] Leck JB \& Park BK (1981) A comparative study of the effects of warfarin and brodifacoum on the relationship between vitamin $\mathrm{K}$ metabolism and clotting factor activity in warfarin-susceptible and warfarin-resistant rats. BiochemPharmacol 30:123-128.

[66] Mancini F, Van Bruggen AH, Jiggins JL, Ambatipudi AC \& Murphy H (2005) Acute pesticide poisoning among female and male cotton growers in India. Internat J Occup Environ Health 11:221-232.

[67] Mason HJ (2000) The recovery of plasma cholinesterase and erythrocyte acetylcholinesterase activity in workers after over exposure to dichlorovos. Occup Med 50:343-347. 
[68] Mathur HB, Agarwal HC, Johnson S \&Saikia N (2005) Analysis of Pesticide Residues in Blood Samples from Villages of Punjab. CSE/PML / PR-21.

[69] McCauley A, Linda Anger KW, Keifer M, Langley R \& Robson GM (2006) Studying health outcomes in farm worker populations exposed to pesticide. Environ Health Perspec114:6-8.

[70] McDiarmid MA \&Gehle K (2006) Preconception brief: Occupational/environmental exposures. MaternE Child Health J 10:123-128.

[71] Mercedes MF, Torres MJ, Vidal AG, Olea-Serrano F \&Olea N (2004) Determination of organochlorine compounds in human biological samples by GCMS/MS. Biomedical Chromatography 18:102.

[72] Moore CF (2003) Silent scourge: Children, pollution, and why scientists disagree. New York: OxfordUniversity Press.

[73] Nickerson K (2006) Environmental contaminants in breast milk.J Midwifery \& Women's Health 51:26-34.

[74] Oluwole O \&Cheke RA (2009) Health and environmental impacts of pesticide use practices: a case study of farmers in Ekiti State, Nigeria. Int J Agr Sustain 7:153-163.

[75] Patil JA, Patil AJ \&Govindwar SP (2003) Biochemical effects of various pesticides on sprayers of grape gardens. Indian J Clinic Biochem 18:16-22.

[76] Peter E (2003) The role of oximes in the management of organophosphorus pesticides poisoning. Oxical Rev 22:165-190.

[77] Pimentel D (2005) Environmental and economic costs of the application of pesticides primarily in the United States.Environ Develop Sustainability 7:229-252.

[78] Pimental D, Acquay H, Biltonen M, Rice P, Silva M \& Nelson J (1992) Eenvironmental and economic costs of pesticide use.Bioscience 42:750-760.

[79] Plianbangchang P, Jetiyanon K \&Wittaya-areekul S (2009) Pesticide use patterns among small-scale farmers: A case study from Phitsanulok, Thailand. SE Asian J Trop Med Public Health 40:401-410.

[80] Pohl HR \&Tylenda CA (2000) Breast-feeding exposure of infants to selected pesticides: a public health viewpoint. Toxicology $\mathcal{E}$ Industrial Health 16:65-77.

[81] Rao P, Gentry AL, Quandt SA, Davis SW, Snively BM \&Arcury TA (2006) Pesticide safety behaviors in Latino farmworker family households. Am J Indust Med 49:271-280.

[82] Remor AP, Totti CC, Moreira DA, Dutra GP, Heuser VD \&Boeira JM (2009) Occupational exposure of farm workers to pesticides: Biochemical parameters and evaluation of genotoxicity. Environ Int 35:273-278. 
[83] Rivas A, Fernandez MF, Cerrillo I, Ibarluzea J, Oiea-Serrano MF, Pedraza V \&Olea N (2001) Human exposure to endocrine disrupters: standardization of a marker of estrogenic exposure in adipose tissue. ActaPatholMicrobioletImmunolScand 109:1.

[84] Ross JH, Driver JH Cochran RC, Thongsinthusak T \& Krieger RI (2001) Could pesticide toxicology studies be more relevant to occupational risk assessment? Ann occupHyg 45:5-17.

[85] Sallam AAA (2008) Determination of profenofos and metalaxyl residues in green onion.J Agric Mansoura Uni 33:351 - 358.

[86] Sallam AAA, El-Massry SA \&Naser IN (2009a) Chemical analysis of mucus from certain land snails under Egyptian conditions.Arch PhytopatholE Plant Prot42:874 -881.

[87] Sallam AAA, Ibrahim MS \& Nasr IN (2006) Monitoring of organochlorine and organophosphorous residues in sediments of river Nile, Egypt. J Agric Mansoura Uni31:2451-2469.

[88] Sallam AAA, Volkmar C \& El-Wakeil NE (2009b) Effectiveness of different bio-rational insecticides applied on wheat plants to control cereal aphids. J Plant Dis EProt116:283- 287.

[89] Sampson EJ \& Baird MA (1979) Chemical inhibition used in a kinetic urease/glutamate dehydrogenase method for urea in serum.Clinic Chem 25:17-19.

[90] Sanborn M, Cole D, Kerr K, Vakil C, Sanin Luz Helena, Bassil K (2004) Pesticides Literature Review: Systematic Review of Pesticide Human Health Effects. Ontario, TheOntarioCollege of Family Physicians.

[91] Schalm OW (1986) Veterinary Hematology (4 $4^{\text {th }}$ ed). Loa and Fibiger, PhiladelphiaUSApp 21-86.

[92] Schell L (1997) Culture as a stressor: A revised model of biocultural interaction. Am J Physical Anthropol 102:67-77.

[93] Schenker MB (2005) Farming and asthma.Occup\& Environ Med 62:211-212.

[94] Schenker MB, et al. (1998) Respiratory health hazards in agriculture. Am J Respiratory $\mathcal{E}$ Critical Care Med 158:1-76.

[95] Shalaby SEM (2006) Comparative haematological and hepatorenal toxicity of IGR, Lufenuron and Profenofos insecticide on albino rats.J EgyptSocToxicol 34:85-98.

[96] Shalaby SEM \&Abd El-Mageed AEM (2010) Biochemical targets affected by subacute doses of new pesticide mixtures tested on Albino rats. J Plant Prot Res 50:513-519.

[97] Shalaby SEM, Abdou G \&Sallam A (2012)Pesticide-residue relationship and its adverse effects on occupational workers in Egypt. ApplBiol Res 14:24-32.

[98] Slotkin T (1999) Developmental cholinotoxicants: nicotine and chlorpyrifos. Environ Health Perspect 107(Suppl. 1):71 - 80. 
[99] Snedecor GW \& Cochran WG (1980) Statistical Methods ( $\left.7^{\text {th }} \mathrm{ed}\right)$. StateUniversity Press, Ames, Iowa, USA.

[100] Soares W, Almeida RMVR \& Moro S (2003) Rural work and risk factors associated with pesticide use in Minas Gerais, Brazil. Cad SaúdePública 19:1117-1127.

[101] Soares WL \&Porto MFS (2012) Pesticide use and economic impacts on health. Rev SaúdePública 46:209-217.

[102] Soomro AM, Seehar GM, Bhanger MI \&Channa NA (2008) Pesticides in the blood samples of spray-workers at agriculture environment: The toxicological evaluation. Pak J Analy Environ Chem 9:32-37.

[103] Sosan MB \&Akingbohungbe AE (2009) Occupational insecticide exposure and perception of safety measures among cacao farmers in southwesternNigeria.Arch Environ OccupHealth 64:185-193.

[104] SosanMB, Akingbohungbe AE, Ojo IAO \&Durosinmi MA (2008) Insecticide residues in the blood serum and domestic water source of cacao farmers in southwesternNigeria.Chemosphere 72:781-784.

[105] Spencer K (1986) Analytical reviews in clinical biochemistry: The estimation of creatinine. Ann Clinic Biochem 23:1-25.

[106] Strong L, Thompson B, Gloria D, William C, Vigoren EM \&Islasllda PTO (2004) Health symptoms and exposure to organophosphorus pesticides in farm workers. An J Ind Med 46:599-606.

[107] Tchounwou PB, Ashour BA, Moreland-Young C \&Raghb DA (2002) Health risk assessment of pesticide usage in Menia El-Kamhprovince of Sharkia governorate in Egypt.Internat J MolecSci 3:1082-1094.

[108] Thompson B, Coronado GD, Grossman JE, Puschel K, Solomon CC, Islas I, Curl CL, Shirai JH, Kissel JC \&Fenske RA (2003) Pesticide take-home pathway among children of agricultural workers: Study design, methods, and baseline findings. J Occup\& Environ Med 45:42-53.

[109] Tijani AA (2006) Pesticide use practices and safety issues: The case of Cocoa farmers in Ondo State, Nigeria. J Human Ecol 19:183-190.

[110] Tomei F, Blagi M, Baccolo TP, Tomao E, Guttoli P \&Rosati MV (1998) Liver damage among environmental disinfestations workers. J OccupHealth 40:193-197.

[111] Travisi M \&Nijkamp P (1998) Valuing environmental and health risk in agriculture: a choice experiment approach to pesticides in Italy. Ecol Econ 67:598-607.

[112] US EPA office of pesticides programs (2002). F.Y 2002 Annual report Willhington, DC: US. Environmental Protection Agency. Available: http://www.epa.gov/oppfead/ annual/2002/2022 annual report. pdf (on 25.3.2004). 
[113] Vega SS (1994) Note on the toxicity of pesticides used in tropical crops.CienciasAmbientales, 11: 181.

[114] Weiss B, Amler S \&Amler RW (2004) Pesticides.Pediatrics113:1030-1036.

[115] Wesseling C, Aragon A, Castillo L, Corriols M, Chaverri F, de la Cruz E, Keifer M, Monge P, Partanen TJ, Ruepert C \& van Wendel de Joode B (2001) Hazardouspesticides in Central America. Int J Occup Environ Health 7:287-294.

[116] Whitmore RW, Kelly JE \& Reading PL (1992) National Home and Garden Pesticide Use Survey. Research Triangle Park, NC, Research Triangle Institute.

[117] WHO (2006) Indoor residual spraying: Use of indoor residual spraying for scaling up global alaria control and elimination. WHO/HTM/MAL/.1112. Global Malaria Programme.

[118] Wolff MS, Engel S, Berkowitz GS, Teitelbaum S, Siskind J, Barr DB \&Wetmur J (2007) Prenatal pesticide and PCB exposures and birth outcomes. Pediatric Research 61:243-250.

[119] World Health Organization (WHO) (2005) The World Health Organization Recommended Classification of Pesticides by Hazard and Guideline to Classification. WHO, Geneva, Switzerland.World Health Organization.Public Health Impact of Pesticides used in Agriculture. WHO, Geneva, Switzerland 51:86.

[120] Xue SZ (1987) Health effects of pesticides: a review of epidemiologic research from the perspective of developing nations. Am J Ind Med 12:269-270.

[121] Yassin MM, Abu Mourad TA \& Safi JM (2002) Knowledge, attitude, practice, and toxicity symptoms associated with pesticide use among farm workers in the Gaza Strip. Occup Environ Med 59:387-394. 
